\title{
ELECTRICAL CONDUCTIVITY AND PH IN SURFACE WATER AS TOOL FOR IDENTIFICATION OF CHEMICAL DIVERSITY
}

\begin{abstract}
In the present study, the creeks and lakes located at the western shore of Admiralty Bay were analysed. The impact of various sources of water supply was considered, based on the parameters of temperature, $\mathrm{pH}$ and specific electrolytic conductivity $\left(S E C_{25}\right)$. All measurements were conducted during a field campaign in January-February 2017. A multivariate dataset was also created and a biplot of $S E C_{25}$ and $\mathrm{pH}$ of the investigated waters was performed. The average temperatures of the investigated waters were $0.10-8.10{ }^{\circ} \mathrm{C}$. The $\mathrm{pH}$ values indicate that most of the water environments of the analysed area are slightly acidic to alkaline (5.26-8.50) with two exceptions: Siodlo II Creek (9.26) and Petrified Forest Creek (8.95), which are characterised by greater alkalinity. At the measurement points closest to the Baranowski Glacier and Ecology Glacier, $S E C_{25}$ values were the lowest $\left(26.8-61.1 \mu \mathrm{S} \cdot \mathrm{cm}^{-1}\right)$, while the remaining values ranged from 79.0 to $382 \mu \mathrm{S} \cdot \mathrm{cm}^{-1}$ for the whole studied area. Based on the results it is concluded that the periodic intensive inflow of ablation waters, combined with morphological changes in the glacier front, causes a significant variability in the outflow network, creating the conditions for changes in basic physicochemical parameters. Moreover, it is observed that local depressions in the terrain form sedimentation traps in which, alongside fine-grained deposits, compounds can accumulate that originate from in situ sedimentation and that are also associated with surface runoff from the melting of snow cover, buried ice and permafrost.
\end{abstract}

Keywords: surface water, electrical conductivity, $\mathrm{pH}$, Admiralty Bay, Maritime Antarctica

\section{Introduction}

Drainage network formation and the feeding of creeks in paraglacial and periglacial environments of the Antarctic Peninsula depends on intensive morphological processes [1-4] related to climate changes that have been observed in recent decades [5-10]. Rapid glacier retreat observed over recent decades [4, 11-14] have resulted in the development a new ice-free areas with an initial drainage network characterised by highly dynamic hydrological processes $[9,15]$.

Water chemistry in the Antarctic has been the subject of several publications, e.g. [16-25]. However, the relation between chemical status and catchment features in Antarctic catchments is one of the less well-known, because of the lack of comprehensive

\footnotetext{
${ }^{1}$ Department of Analytical Chemistry, Faculty of Chemistry, Gdansk University of Technology, ul. G. Narutowicza 11/12, 80-233 Gdańsk, Poland, phone +48 5834721 10, fax: +48 583472694 , email: potapowicz.joanna@gmail.com,zanpolko@pg.edu.pl

${ }^{2}$ Institute of Geography, Kazimierz Wielki University, pl. Kościelecki 8, 85-033, Bydgoszcz, Poland, phone +48 5234962 72, email: seb.czap@ukw.edu.pl

${ }^{3}$ Department of Water and Waste Water Technology, Faculty of Civil and Environmental Engineering, Gdansk University of Technology, ul. G. Narutowicza 11/12, Gdańsk 80-233, Poland

*Corresponding author: dszum@ukw.edu.pl
} 
information about, for example, soil patterns, permafrost occurrence, groundwater conditions and geochemistry. The collecting of this kind of data is typical in hydrological and hydrochemical analysis of catchments located in areas more easily accessible to field work, aerial photography, laser scanning, etc. Furthermore, the rapid glacier retreat that has been observed in recent decades in this area, e.g. $[5,6,8,10,26]$, is causing rapid changes in the water network and has led to the observation of two main types of catchments: young paraglacial catchments, with creeks being fed by glacier thawing, and previously formed catchments without glacier-melt water supply.

Research to date indicates that the chemical status of surface waters in this area is shaped by both natural factors such as geological structure, marine aerosols, etc. [20-22, 24, 25] as well as anthropogenic factors. The infrastructure of research stations may have a negative impact on the environment in the form of pollutant emissions and is not without impact on the sensitive ecosystems occurring there [17, 24, 25]. In addition, the development of tourism has also been seen in recent years [24, 25], which is associated with an increase in pollutant emissions due to the higher frequency of passing ships. Therefore, one should agree with Kroto et al. [27], that the need to share and promotion the results of research related to environment arises. It is important especially in terms to sensitive polar ecosystems. Antarctica is also influenced by global anthropogenic activities, mainly due to the transport of pollutants over long distances by atmospheric (long range atmospheric transport, LRAT) [25]. The main aim of this study is to analyse the relation between electrical conductivity $\left(S E C_{25}\right)$ and $\mathrm{pH}$ of water in creeks in both types of catchments. The detailed chemical status of some of the creeks has been provided before on the basis of samples collected in 2016 [25], but the limited number of sampling points along the creeks caused some difficulties with interpretation of factors related to diversification of the catchment. Moreover, taking into account a limited numbers of samples subjected to chemical analyses in Poland (limited on account of transportation limits and high analysis costs) it is important to find the general rules of chemical inorganic diversity based on simple measurements performed in situ in the field.

Hence, this paper aims to interpret $S E C_{25}$ and $\mathrm{pH}$ data based on creeks and lakes in the western shore of Admiralty Bay in relation to the location of sampling sites (Fig. 1). This approach allowed us to analyse creeks with regard to the impact of the various water supply sources to determine the factors that alter water composition: e.g. soil background (geochemical factor), marine aerosols, glacier retreat, meteorological conditions, human activity and transport of nutrients by biovectors, e.g. penguins.

\section{Study area}

The research area is located on King George Island (the western shore of Admiralty Bay, South Shetland Islands, Antarctic Peninsula), $90 \%$ of whose surface $\left(1,310 \mathrm{~km}^{2}\right)$ is permanently glaciated [11] (Fig. 1). Deglaciation [14, 28] and related changes in the water network plays an important role in hydrological processes and is one of the factors that determines the chemical status of water bodies in the study area [25]. Changes in the distribution of glaciers at the western shore of Admiralty Bay between 1979 and 2014 are presented in Figure 1. 


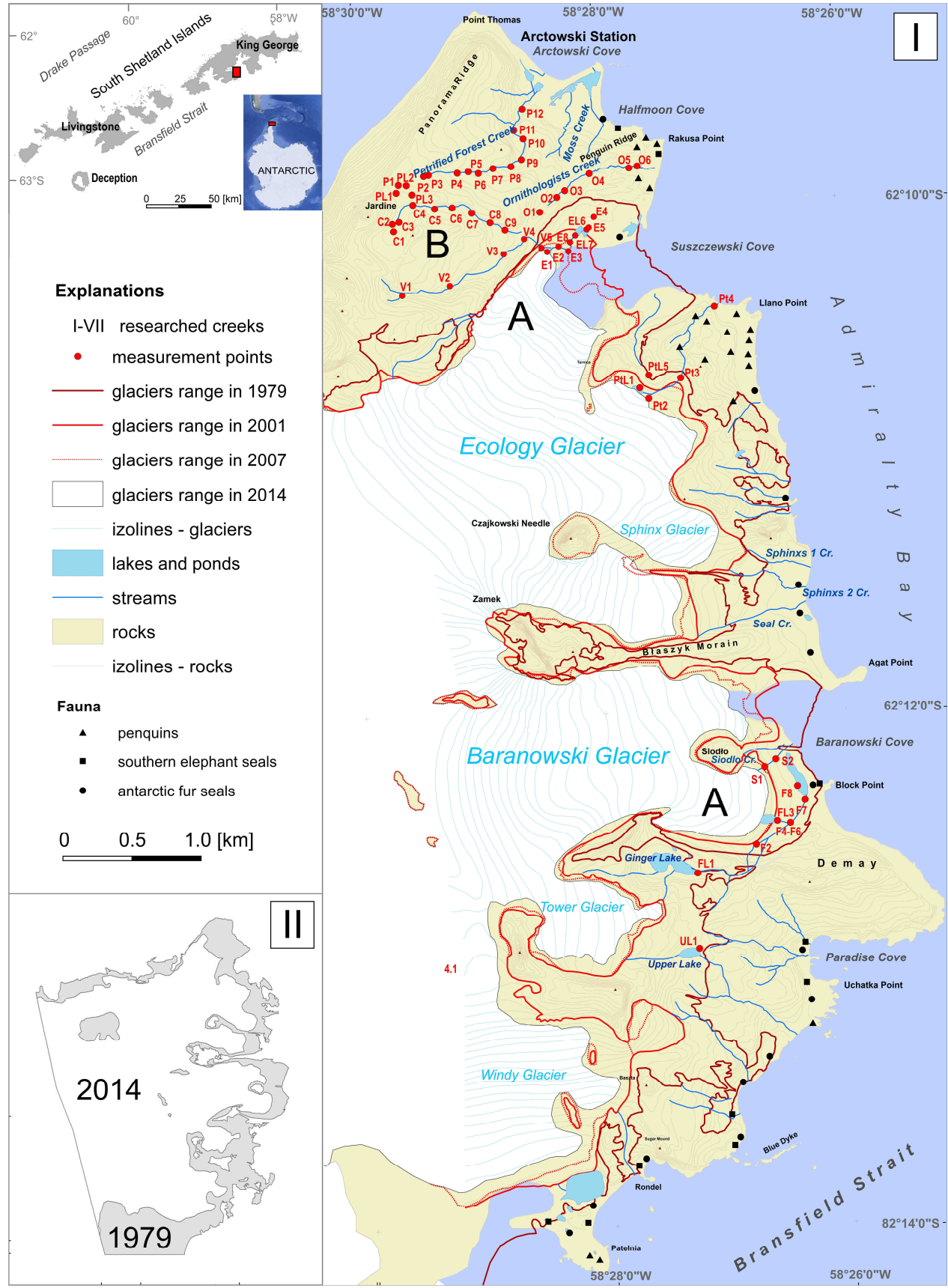

Fig. 1. Map of the western shore of Admiralty Bay (Maritime Antarctica) showing the location of the measuring points (I) and glaciers' retreat between 1979 and 2014 (II): A - creeks draining the area uncovered by glacier after 1979, B - creeks draining the area uncovered by glacier before 1979; P - measured points on creeks, PL - measured points on lakes (prepared based on [29]; Landsat image LC82181032014016LGN00 obtained from www.usgs.gov; GoogleEarth application) 
The most significant changes have been observed in the parts of the glacier forefield that ranged close to the seashore in 1979 (Fig. 1). Petlicki et al. [14] calculated the mean vertical changes in Ecology Glacier from 1979 to 2016 at $-57.9 \pm 10.1 \mathrm{~m}$ for the entire period, and $-1.6 \pm 0.3 \mathrm{~m}$ per year. The authors' own calculation for the area presented in Figure 1 shows that the glacier horizontal retreat exceeded $700 \mathrm{~m}$ in some sections of the Ecology Glacier, $600 \mathrm{~m}$ in parts of the Baranowski Glacier, and 1,500 $\mathrm{m}$ at the border of the Tower and Windy glaciers. The total area of newly-formed ice-free terrain amounted to $8.67 \mathrm{~km}^{2}$. This area has been subject to intensive morphological processes [30] and many new riverbeds have been established [15].

The intensive deglaciation is caused by an increase in mean annual air temperature during the second half of $20^{\text {th }}$ century in the Maritime Antarctic, e.g. [5, 6, 9, 10]. Temperature changes observed in research area are part of global climate warming e.g. [26, 31]. According to Turner et al. [32] the temperature increase in Antarctic Peninsula of $\sim 0.5^{\circ} \mathrm{C} /$ decade since 1950 , however slight decrease has been recorded at the beginning of $21^{\text {st }}$ century $[33,34]$.

In 2017 the mean annual air temperature in the Bellingshausen station on King George Island was $-1.8{ }^{\circ} \mathrm{C}$, which is higher than the mean for the years $1968-2017\left(-2.3{ }^{\circ} \mathrm{C}\right)$ (calculation based on data provided at www.rp5.ru). Total annual precipitation in 2017 was $727 \mathrm{~mm}$, which was higher than the long-term mean of $697 \mathrm{~mm}$. Measurements of $S E C_{25}$, $\mathrm{pH}$ and $T$ were carried out between January $7^{\text {th }}$ and February $7^{\text {th }} 2017$. At the time of measuring of $\mathrm{pH}, S E C_{25}$ and $T$ in water (Jan 7 to Feb 7), average daily temperatures ranged between 1 and $6{ }^{\circ} \mathrm{C}$ (Fig. 2). The maximum daily temperature $\left(10.1{ }^{\circ} \mathrm{C}\right)$ was noted on February $8^{\text {th }}$, and the minimum $\left(0.1{ }^{\circ} \mathrm{C}\right)$ on January $16^{\text {th }}$. Snow cover occurred at the beginning of January and it rained on several days in both months. Total daily precipitation did not exceed 5-10 mm (Fig. 2). In addition to changes in air temperature, the accompanying processes have been also observed Maritime Antarctica, inter alia permafrost degradation [35], which indicates the impact of climate change on polar heat exchange systems.

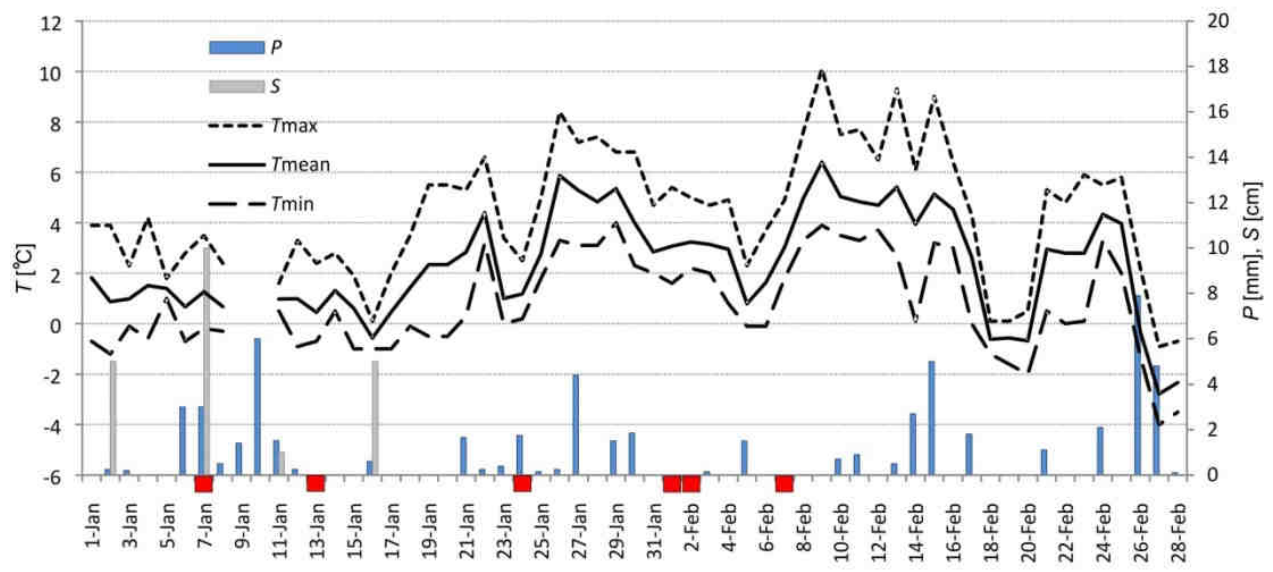

Fig. 2. Weather conditions Jan 1 to Feb 28, 2017 based on data from the meteorological station in the vicinity of the Arctowski Polish Polar Station. Abbreviations: $P$ - precipitation, $S$ - snow depth, $T$ - temperature, days of measurements are marked in red 


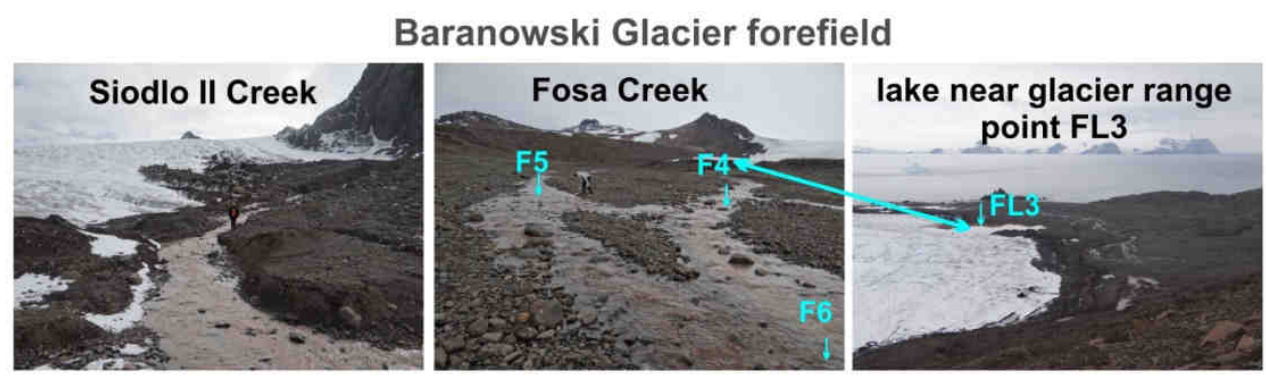

Ecology Glacier forefield
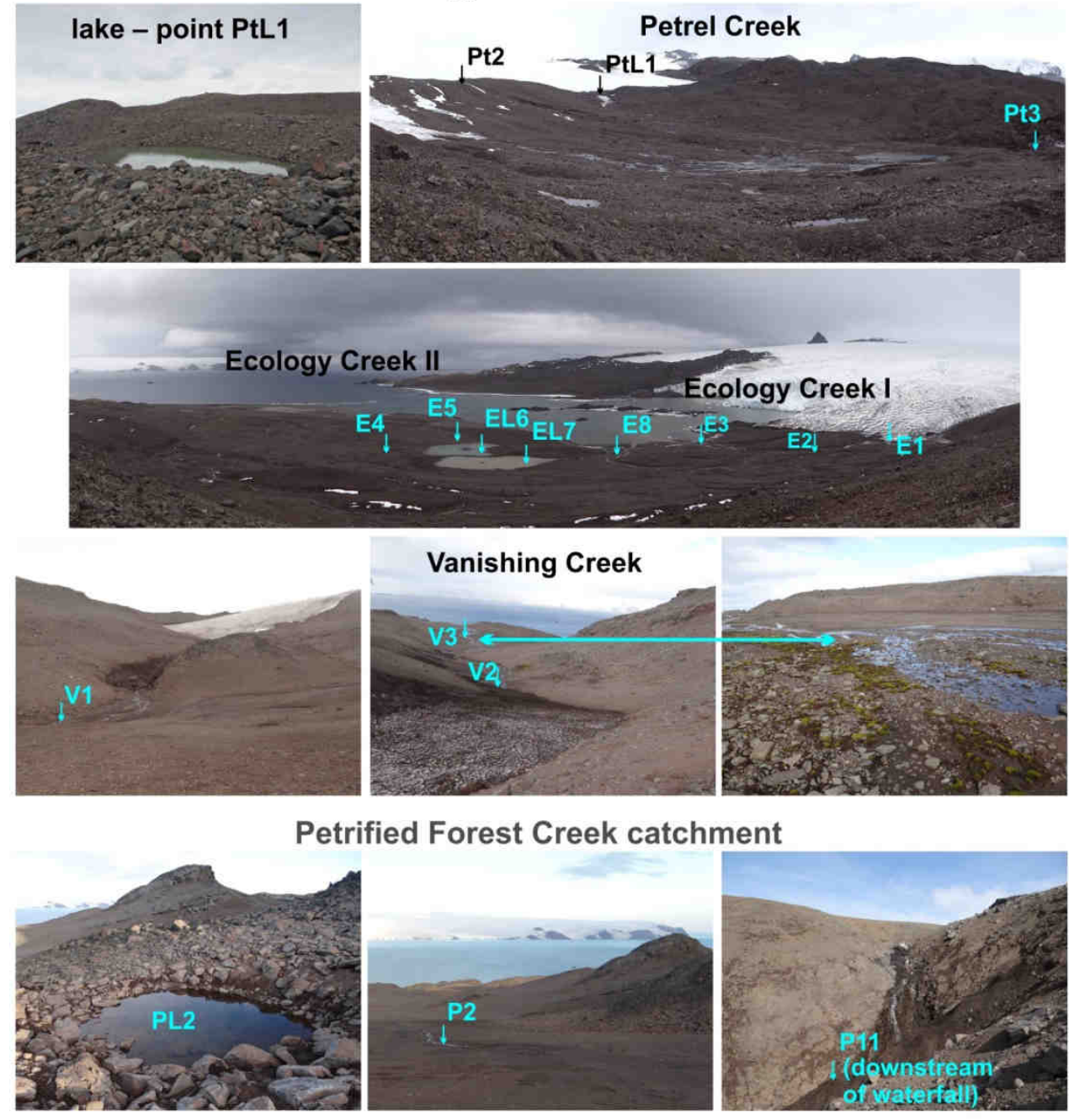

Fig. 3. Studied creeks and lakes at the western shore of Admiralty Bay (Feb-Jan 2017) 
Taking into account the main geographical features of the research area, several main types of landscape can be distinguished:

1) new and relatively young paraglacial terrain in the forefields of glaciers;

2) areas previously uncovered by glaciers;

3) nunataks and their surroundings; and

4) beaches partially inhabited by Antarctic fauna.

The researched creeks (and lakes located in the watersheds) differ in terms of landscape (Fig. 3) and main factors determining morphological and hydrological processes. The catchments of Petrel Creek, Siodlo II and Fosa Creek are of the first and third landscape types. However, the catchments of Petrified Forest Creek, Czech Creek, Vanishing Creek and Ornithologists Creek are the second of the aforementioned landscape types. The mouth sections of all creeks, except Czech Creek and Vanishing Creek, are located in beach landscapes. In the case of Petrified Forest Creek, the beach has been changed by the human impact of the Arctowski station.

In terms of their geological structure, watersheds of Petrified Forest Creek, Czech Creek, Vanishing Creek and Ornithologists Creek are located within the Arctowski Cove Formation and the Point Thomas Formation, terrestrial volcanic and sedimentary groups [36]. In these units, basalt, and basaltic and andesite lava are interlayered with breccias and pyroclastics with andesite conglomerate lag intercalations. The watersheds of Ecology Creek and Petrel Creek are located in the forefield of Ecology Glacier, whereas the watershed of Fosa Creek is in the forefield of the Baranowski Glacier (Fig. 1). The highest sections of these watersheds are connected with the Llano Point formations and feature basaltic andesite lavas, alternating with scoria and breccias [36]. However, the forefield of the Baranowski Glacier also includes the Demay Point Formation consisting mainly of acidic volcanic rocks with andesite agglomerate and petrified wood fragments. Therefore, most of these particular areas consist of ground and marginal moraines - features of considerable hydration and low compaction.

An additional factor related to watershed processes is the discontinuous permafrost that occurred on King George Island at altitudes above 10-20 m a.s.1. [9, 30] with thicknesses ranging from 20 to $100 \mathrm{~cm}$ and active layer depth ranging from 50 to $180 \mathrm{~cm}$. Additionally, the lower courses of Ornithologists Creek are inhabited by a few species of flora. This may change the chemical composition of the water, mainly by increasing nutrient contents [37]: inter alia $\mathrm{PO}_{4}{ }^{3-}, \mathrm{NO}_{3}{ }^{-}, \mathrm{NH}_{4}{ }^{+}$, and some microelements (e.g. Zn, $\mathrm{Cu}, \mathrm{Sr}$ ) [25]. Moreover, the areas recently uncovered by glaciers differ from the ice-free catchments in that they have a higher content of $\mathrm{Fe}$ and $\mathrm{Al}$ in water [25].

\section{Methods}

Research was conducted on nine creeks draining the ice-free area at the western shore of Admiralty Bay, between the Baranowski Glacier and the Arctowski Oasis, and on six lakes in the researched catchments (Fig. 1). Three streams drain the immediate forefield of the Baranowski Glacier (Petrel Creek - $0.33 \mathrm{~km}$, Siodlo II Creek - $0.33 \mathrm{~km}$ and Fosa Creek - $1.1 \mathrm{~km}$, downstream of Ginger Lake), and two drain Ecology Glacier (two short creeks of $0.2 \mathrm{~km}$ length, referred to in this work as Ecology Creek). In contrast to the other streams, the upper course of Fosa Creek is separate from direct glacier-melt water (Fig. 1). The other four studied streams (Vanishing Creek - $1.24 \mathrm{~km}$, Czech Creek - $1.08 \mathrm{~km}$, Ornithologists Creek - $0.92 \mathrm{~km}$ and Petrified Forest Creek - $1.62 \mathrm{~km}$ ) are south-west and south of Henryk 
Arctowski Research Station (Fig. 1). In all watercourses, measurements of $S E C_{25}, \mathrm{pH}$ and $T$ were taken during a field campaign in January-February 2017 using a CC-105 conductivity meter and a CP-105 pH-meter manufactured by ELMETRON. The resolution of the Elmetron device was \pm 0.02 for $\mathrm{pH} ; \pm 0.1 \mathrm{mV}$ for conductivity and $\pm 0.8{ }^{\circ} \mathrm{C}$ for temperature. The person measuring the field had lates gloves on. Particular attention was paid to ensure that the heads of the $\mathrm{pH}$ meter and conductivity meter are completely submerged under water. Measurements were taken on the surface water about $50 \mathrm{~cm}$ from the creek shore. The points where the water had laminar flow were selected as the measurement site.

Measurements sites were determined taking into account catchments' diversification and their possibility of supply by glacier-melt water. The was a total of 59 measured points (Petrified Forest Creek - 15; Czech Creek - 9, Vanishing Creek - 5, Ornithologists Creek 6; Ecology Creek - 8; Petrel Creek - 5; Siodlo II Creek - 2; and Fosa Creek with the Upper Lake - 9). In the cases of Fosa Creek and Siodlo II Creek, measurements were taken three times (7 Jan, $10 \mathrm{Jan}, 24 \mathrm{Jan}$ ), according to the progress of snowing and glacier ablation. In the other watercourses and lakes, measurements were conducted once between 1 st and 7 th February. There were 80 measurements in total (including repeat measurements in selected creeks).

\section{Results}

The statistical characteristics of the temperature, $\mathrm{pH}$ and conductivity values could be found in Table 1 for the entire data set, and in Table 2 for particular catchments. The temperature of water ranged between 0.1 and $8.1^{\circ} \mathrm{C}$. The lowest temperatures were observed in creeks fed by melt water, namely Ecology and Siodlo II (Table 2). The pH of the waters ranged from 5.26 to 9.26. The skewness and kurtosis values indicate that temperature and conductivity were normally distributed in the data set, but $\mathrm{pH}$ has a strongly leptokurtic data distribution.

Table 1

Basic characteristics calculated based on entire datasets of measurement points

\begin{tabular}{|c|c|c|c|c|c|c|c|}
\hline & Mean & Median & Min. & Max & St. dev. & Skewness & Kurtosis \\
\hline$T\left[{ }^{\circ} \mathrm{C}\right]$ & 3.65 & 3.70 & 0.10 & 8.10 & 2.11 & 0.082 & -1.002 \\
\hline$S E C_{25}\left[\mu \mathrm{S} \cdot \mathrm{cm}^{-1}\right]$ & 127 & 104 & 26.8 & 382 & 75.0 & 1.132 & 1.228 \\
\hline $\mathrm{pH}[-]$ & 7.81 & 7.84 & 5.26 & 9.26 & 0.62 & -1.118 & 5.323 \\
\hline
\end{tabular}

$T$ - temperature, $S E C_{25}$ - conductivity

In terms of the distribution of measured parameters in individual catchments (Table 2), among the type-A streams (with the possibility of being fed by glacial melt water) Siodlo II Creek distinguishes itself for its low water temperature (Fig. 4A). In that creek, when the measurements were taken, all the water actually came from glacier ablation (Fig. 1, Fig 3). Similarly low water temperatures were measured at point FL3 in Fosa Creek (Fig. 4A) on all measurement dates, and in profile F4 on 10 and 24 January. Point FL3 is water of the lake at the front of Baranowski Glacier, while point F4 is located on its outflow stream (Fig. 1, Fig. 3). Point F5 is located in the profile at the end of the upper course of Fosa Creek, below point F2. Next, point F6 is after the confluence of Fosa Creek (F5) and its tributary from the lake (F4). The temperature distribution at these points indicated a strong inflow of glacier melt waters on January 10 and 24, which was the result of rising air temperatures in January (Fig. 2) and the associated intensive ablation. Regarding 
watercourses without ablation water supply (Table 2, Fig. 4B), among the four analysed watercourses, Petrified Forest Creek is distinguished by its low water temperature, while the low water temperatures are created in the middle of its course (points P3-P5 and P9) (Fig. 1, Fig. 4).

Table 2

Basic characteristics of selected creeks (including lakes located in a particular catchment): A - catchments with glacier-melt supply of creeks, B - catchment without glacier-melt supply of creeks

\begin{tabular}{|c|c|c|c|c|c|c|}
\hline Research area & Mean & Median & Min & Max & $\begin{array}{c}\text { Number of } \\
\text { measurements }\end{array}$ & \\
\hline Fosa & \multicolumn{4}{|c|}{ January 7, 10, 24} & \multirow{4}{*}{26} & \multirow{16}{*}{$\mathbf{A}$} \\
\hline$T\left[{ }^{\circ} \mathrm{C}\right]$ & 4.87 & 5.20 & 1.00 & 8.10 & & \\
\hline$S E C_{25}\left[\mu \mathrm{S} \cdot \mathrm{cm}^{-1}\right]$ & 79.0 & 86.7 & 26.8 & 119 & & \\
\hline pH [-] & 7.84 & 7.85 & 7.11 & 8.50 & & \\
\hline Siodlo II & \multicolumn{4}{|c|}{ January 7, 10, 24} & \multirow{4}{*}{6} & \\
\hline$T\left[{ }^{\circ} \mathrm{C}\right]$ & 0.77 & 0.60 & 0.10 & 2.00 & & \\
\hline$S E C_{25}\left[\mu \mathrm{S} \cdot \mathrm{cm}^{-1}\right]$ & 81.5 & 82.9 & 61.1 & 99.0 & & \\
\hline pH [-] & 8.91 & 8.94 & 8.36 & 9.26 & & \\
\hline Petrel & \multicolumn{4}{|c|}{ January 13} & \multirow{4}{*}{5} & \\
\hline$T\left[{ }^{\circ} \mathrm{C}\right]$ & 3.72 & 3.80 & 1.30 & 6.70 & & \\
\hline$S E C_{25}\left[\mu \mathrm{S} \cdot \mathrm{cm}^{-1}\right]$ & 99.7 & 53.7 & 43.0 & 290 & & \\
\hline pH [-] & 7.53 & 7.43 & 6.86 & 8.47 & & \\
\hline Ecology & \multicolumn{4}{|c|}{ February 1} & \multirow{4}{*}{8} & \\
\hline$T\left[{ }^{\circ} \mathrm{C}\right]$ & 2.81 & 3.15 & 0.10 & 6.70 & & \\
\hline$S E C_{25}\left[\mu \mathrm{S} \cdot \mathrm{cm}^{-1}\right]$ & 116 & 115 & 28.1 & 232 & & \\
\hline pH [-] & 7.67 & 7.78 & 7.23 & 7.97 & & \\
\hline Vanishing & \multicolumn{4}{|c|}{ February 1} & \multirow{4}{*}{5} & \multirow{16}{*}{ B } \\
\hline$T\left[{ }^{\circ} \mathrm{C}\right]$ & 3.42 & 3.40 & 1.40 & 5.50 & & \\
\hline$S E C_{25}\left[\mu \mathrm{S} \cdot \mathrm{cm}^{-1}\right]$ & 88.8 & 95.2 & 49.2 & 110 & & \\
\hline pH [-] & 7.91 & 7.81 & 7.70 & 8.17 & & \\
\hline Czech & \multicolumn{4}{|c|}{ February 7} & \multirow{4}{*}{9} & \\
\hline$T\left[{ }^{\circ} \mathrm{C}\right]$ & 3.40 & 3.40 & 1.70 & 4.20 & & \\
\hline$S E C_{25}\left[\mu \mathrm{S} \cdot \mathrm{cm}^{-1}\right]$ & 135 & 137 & 73.0 & 169 & & \\
\hline pH [-] & 7.61 & 7.64 & 7.18 & 7.89 & & \\
\hline Ornithologists & \multicolumn{4}{|c|}{ February 7} & \multirow{4}{*}{6} & \\
\hline$T\left[{ }^{\circ} \mathrm{C}\right]$ & 4.72 & 4.90 & 1.60 & 7.00 & & \\
\hline$S E C_{25}\left[\mu \mathrm{S} \cdot \mathrm{cm}^{-1}\right]$ & 180 & 167 & 120 & 244 & & \\
\hline pH [-] & 6.70 & 6.94 & 5.26 & 8.11 & & \\
\hline Petrified Forest & \multicolumn{4}{|c|}{ February 2} & \multirow{4}{*}{15} & \\
\hline$T\left[{ }^{\circ} \mathrm{C}\right]$ & 2.93 & 2.30 & 1.00 & 6.20 & & \\
\hline$S E C_{25}\left[\mu \mathrm{S} \cdot \mathrm{cm}^{-1}\right]$ & 230 & 202 & 171 & 382 & & \\
\hline pH [-] & 7.99 & 7.93 & 7.44 & 8.95 & & \\
\hline
\end{tabular}

Analysing the spatial distribution of conductivity in the studied waters, the lowest $S E C_{25}$ values $\left(26.8-61.1 \mu \mathrm{S} \cdot \mathrm{cm}^{-1}\right)$ was found in Siodlo II Creek and Fosa Creek at points FL3, F4 and F8, and in Ecology Creek at points E1-E3, i.e. the measurement sections closest to the Baranowski and Ecology glaciers' fronts (Fig. 1, Fig. 4A). Higher $S E C_{25}$ values $\left(79.0-382 \mu \mathrm{S} \cdot \mathrm{cm}^{-1}\right)$ in the catchments fed with glacial waters were recorded in the upper part of the Fosa Creek catchment (in the waters of Ginger Lake and Upper Lake and in Fosa Creek), in Ecology Creek at points E4, E5, E8, EL6 and EL7, and in Petrel Creek at 
point PtL5. Points marked "EL" represent lakes in the paraglacial zone, which are fed not only by rainwater but also by melt water from dead ice and buried ice in fresh moraine deposits. Points E4, E5 and E8 in the Ecology Glacier forefield were small streams flowing out from these lakes.

The recorded $\mathrm{pH}$ values indicated that the majority of analysed aquatic environments in the area are either neutral or slightly alkaline (Fig. 4). However, $\mathrm{pH}$ at the measuring points in Siodlo II and point PL1, which constitutes a small lake in the upper part of the Petrified Forest Creek catchment, reaches values close to 9, indicating that the waters are more strongly alkaline (Table 2, Fig. 4).

Based on the analysis of the Pearson correlation matrix (Table 3), there was a statistically significant positive correlation $(p<0.05)$ between $S E C_{25}$ and altitude. The obtained result was probably related to low $S E C_{25}$ values in the Fosa creek system and high values in the Pertified Forest creek, which both represent the largest number in the data set (Table 2). First mentioned group of measurement points was located mainly at low altitudes, whereas second group was located along south-east slopes of the Panorama Ridge and is characterized by higher altitudes. Moreover, the Fosa creek system was fed mostly by glacial inflow against to the Petrified Forest creek, which is fed by the melting of snow cover, buried ice and permafrost mostly. The analysed dataset showed no correlation between $\mathrm{pH}$ and $S E C_{25}$.

Figure 5 is a biplot of $\mathrm{pH}$ against $S E C_{25}$. As the spread of points shows, the examined watercourses exhibit a characteristic relationship between $\mathrm{pH}$ and $S E C_{25}$. Waters fed by glacier ablation are grouped in an $S E C_{25}$ zone not exceeding $100 \mu \mathrm{S} \cdot \mathrm{cm}^{-1}$ (zone I in Fig. 1) while waters in catchments without glacial supply, which at the same time have been functioning in periglacial conditions for longer, are in the $S E C_{25}$ range of $100-250 \mu \mathrm{S} \cdot \mathrm{cm}^{-1}$, with only a few exceptions above these values (zones I and II in Fig. 5). Moreover, samples that represent relatively early deglaciated catchments (Petrified Forest creek, Czech creek, Ornithologists creek) differ in term of $\mathrm{pH} / \mathrm{SEC}_{25}$ relation (III in Fig. 5) against direct glacier forefields area (I and II). The widest spread of $S E C_{25}$ values is for the forefield of Ecology Glacier, with values ranged from 28.1 to $232 \mu \mathrm{S} \cdot \mathrm{cm}^{-1}$. In terms of $\mathrm{pH}$, Siodlo II was clearly distinguished for having the highest values (the most alkaline of the researched waters) and Ornithologists Creek for having the lowest (the most acidic). Last mentioned creek, especially its mouth section was place of is the place of existence of the Antarctic birds (penguins, skuas), southern elephant seals. Moreover, this part of creek catchment was cover by patches of mosses.

Values of Pearson's correlation coefficient, $r$ calculated based on complete datasets of measurement points. Statistically significant correlation are given in bold $(p<0.05)$

\begin{tabular}{|c|c|c|c|c|}
\hline & $\boldsymbol{T}$ & $\boldsymbol{S E C}$ & $\mathbf{p H}$ & $\boldsymbol{h}$ \\
\hline$T$ & 1.000 & & & \\
\hline$S E C$ & 0.108 & 1.000 & & \\
\hline $\mathrm{pH}$ & -0.189 & -0.118 & 1.000 & \\
\hline$h$ & 0.005 & $\mathbf{0 . 4 4 7}$ & 0.026 & 1.000 \\
\hline
\end{tabular}

$T$ - temperature, $S E C$ - conductivity, $h$ - altitude 

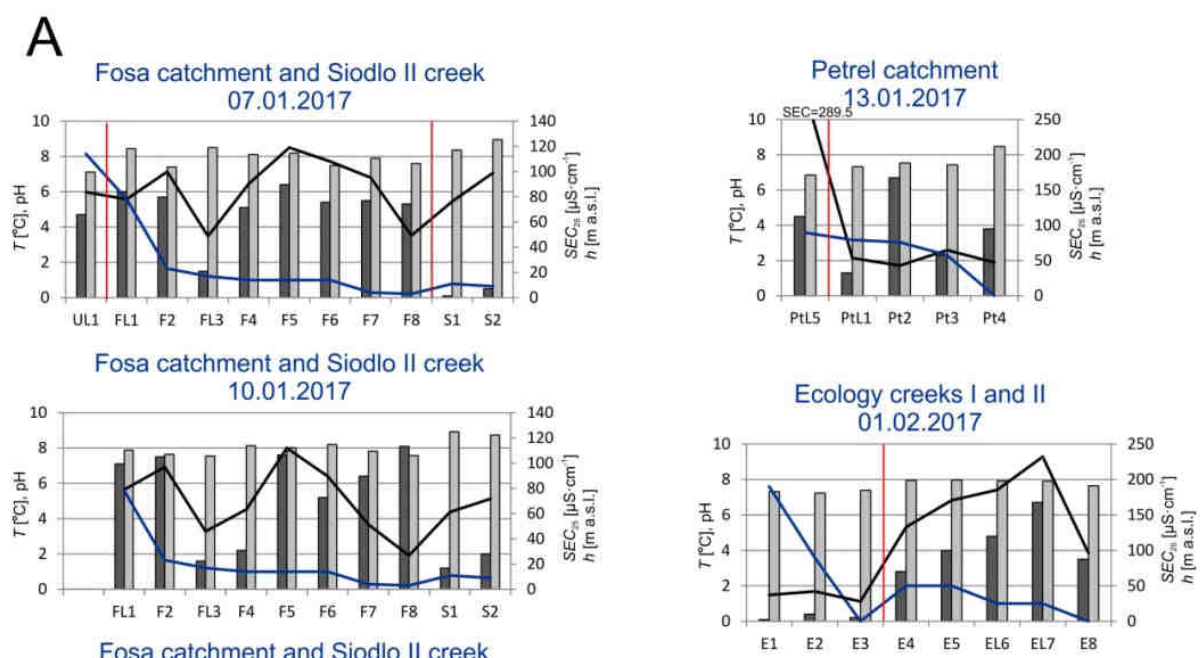

Fosa catchment and Siodlo II creek
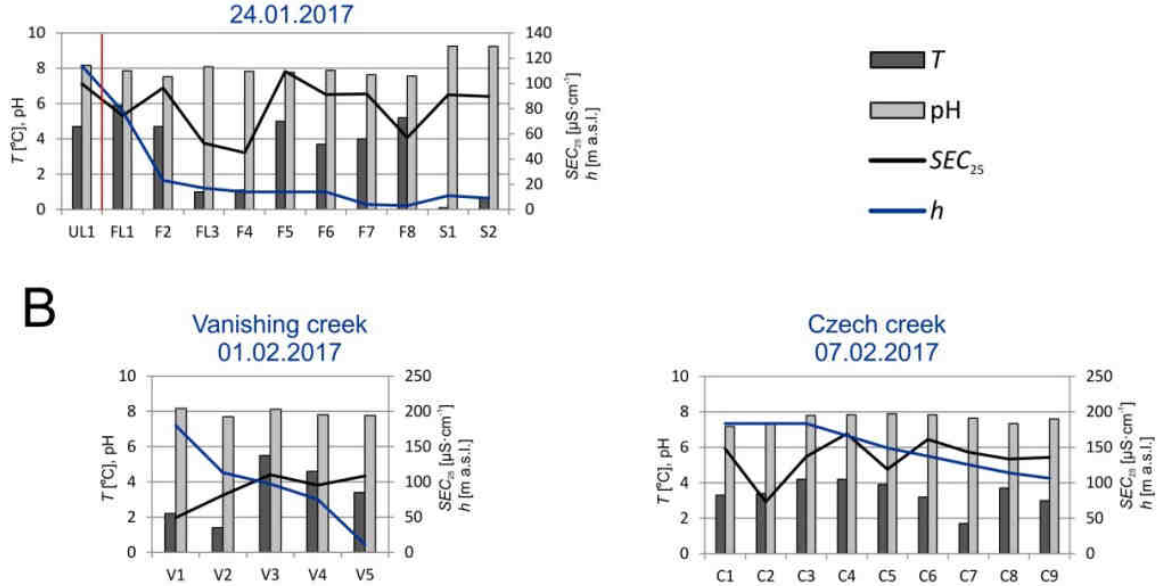

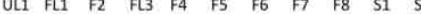

Ornithologists creek

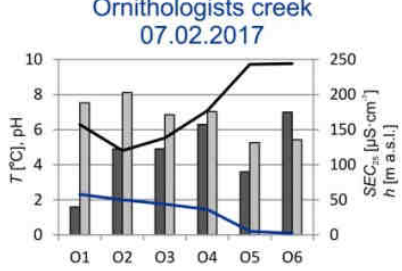

Petrified Forest catchment 02.02.2017

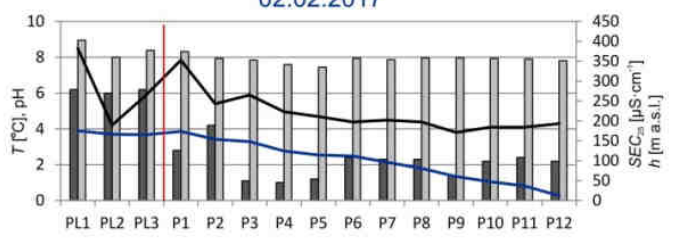

Fig. 4. $T, S E C_{25}$ and $\mathrm{pH}$ values at the background of the longitudinal profiles of measured points: A - catchments with glacier-melt supply of creeks, B - catchment without glacier-melt supply of creeks. Red lines separate differ creeks' fluvial systems, and also lakes that are not include into fluvial systems. Samples UL1, PTL5, PL1-PL3 represent lakes without connection with surface drainage systems. Other ' $L$ ' samples represent lakes which are part of the surface drainage systems 


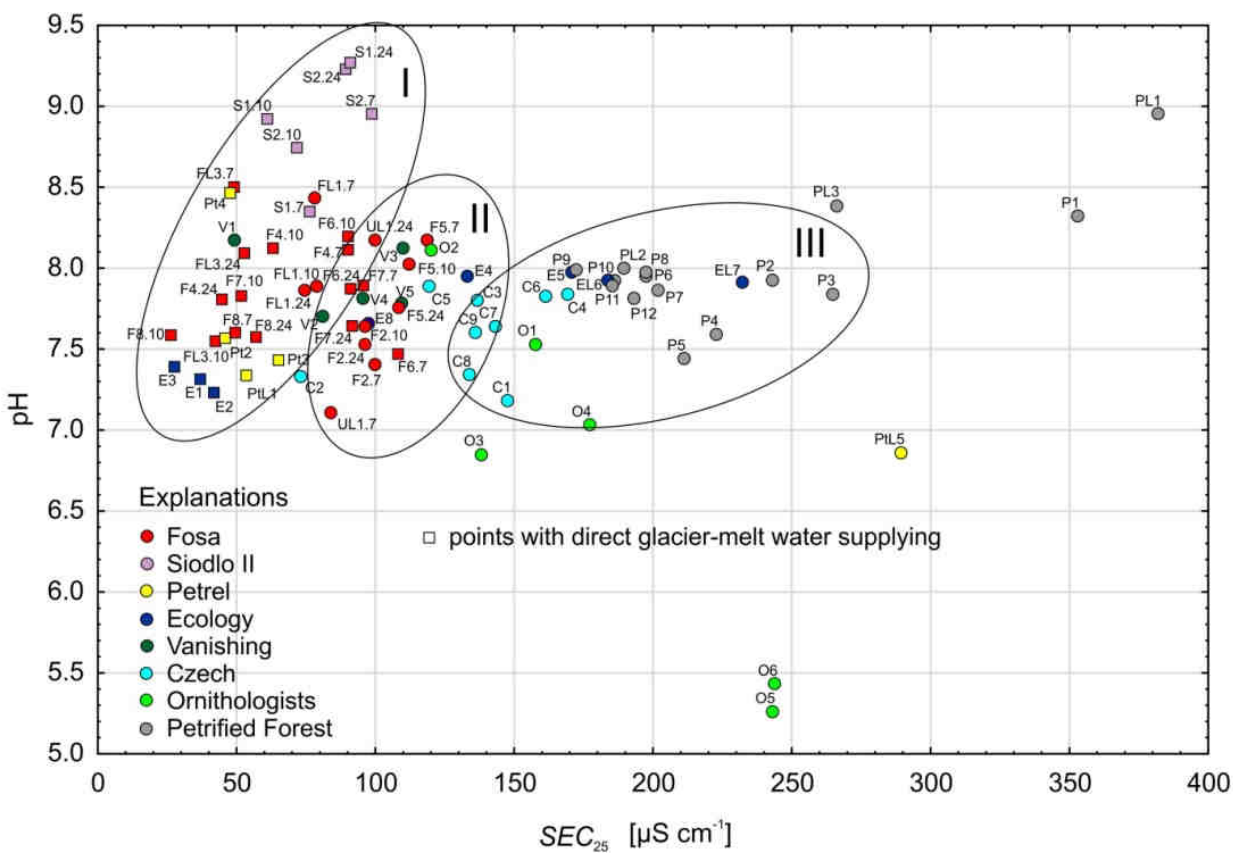

Fig. 5. Biplot of $S E C_{25}$ and $\mathrm{pH}$ of investigated waters at the western shore of Admiralty Bay (numbers of points corresponds to Fig. 1). I-III - explained in the text

\section{Discussion}

The periodic intense inflow of ablation water has combined with morphological changes in the glacier front to cause significant variability in the drainage network, both spatially and temporally. In the course of field measurements performed in 2017 along the analysed watercourses, a cascade system of longitudinal profiles was observed. Sections of low longitudinal slope and considerable width coexist alternately with sections featuring high longitudinal slopes. In the first type, small shallow lakes may occur periodically, but in the second, steps or waterfalls often exist (Fig. 4). Studies of the chemical properties of waters at the western shore of Admiralty Bay to date have mainly been carried out in the mouth sections of watercourses [23, 25, 38]. The $S E C_{25}$ results from measurements made for this work are similar to other authors' results for stream-mouth sections, and show generally lower values for glacially fed catchments and higher values in non-glaciated catchments, while the highest are in zones under the direct influence of aerosols or exposed to periodic influxes of sea waters. Works by Nedzarek and Pociecha [20] and Nedzarek et al. [22] presenting selected chemical variables for lakes and flowing waters in the Arctowski Oasis (at a different distance from the Admiralty Bay coast), showed that increases in $S E C_{25}$ accompanied increases in concentrations of the tested ions of $\mathrm{Cl}^{-}, \mathrm{Na}^{+}$ and $\mathrm{SO}_{4}{ }^{2-}$ that generally dominate in the ionic composition of waters in this area $[21,25]$. Furthermore, the $S E C_{25}$ in the results obtained by Nedzarek and Pociecha [20] show the largest fluctuations over time in lakes close to the bay shoreline and those in range of penguin colonies. $S E C_{25}$ values in waters further from marine influences fluctuate less over 
time. Research conducted in 2017 shows that the maximum instantaneous $S E C_{25}$ values in summer (Fig. 4) in waters remote from the ocean's influence were recorded in small lakes in the very young moraine zone $\left(290 \mu \mathrm{S} \cdot \mathrm{cm}^{-1}\right.$ at point PTL5 near Petrel Creek) and in the non-glaciated catchment of Petrified Forest Creek (382 $\mu \mathrm{S} \cdot \mathrm{cm}^{-1}$ at point PL1) (Table 2). Obtained values are higher than presented in previous studies of surface waters in this area $[20,22,25]$. It is difficult to clearly determine the difference in conductivity between previous research and those presented in this article. Measurements were taken in any case during austral summer (January-February). In 2017, it was found that Petrified Forest Creek is fed by melting snow cover and permafrost [39]. In addition, processes associated with permafrost such as solifluction, cryoturbation have an impact on the water chemistry in this creek [38, 40-42]. When comparing $S E C_{25}$ values, it is worth considering the aspect of increasing the drainage network over the years due to the increase in the depth of the permafrost active zone. This theory is not unequivocally confirmed in the literature, although Kejna et al. [10] observed that the climate conditions on King George Island are characterized by annual variability due to the interaction of ocean, sea ice and atmosphere. It is possible that due to climate change permafrost in this area, among others Petrified Forest Creek degrades and the thickness of the active layer increases. Higher $S E C_{25}$ values have only been registered by Zwolinski [38] in the mouth sections of marine-influenced watercourses during the winter thaw (with the activation of significant amounts of ions accumulated in snow cover). In the upper course of the Petrified Forest catchment, the high $S E C_{25}$ value of $353 \mu \mathrm{S} \cdot \mathrm{cm}^{-1}$ was recorded at point $\mathrm{P} 1$, where water is observed to flow in this period from sediments to the surface in the main channel of the watercourse. Further down the course the flow ceased, only to reappear as small outflows from sediments at points P3 and P4 and again as a larger outflow in the main channel at point P5. The low water temperatures recorded at these points (Fig. 4) attest to the possibility of water being supplied from the melting of permafrost and/or buried lumps of dead ice. Similar water temperature drops along the course of a stream accompanied by changes in $S E C_{25}$ values were also recorded along the course of other streams in non-glaciated catchments - in Czech Creek and Ornithologists Creek (Fig. 4). Changes in the temperature and conductivity of water occurred in sections with changes of slope in the longitudinal profile, which could be associated with a change in how the watercourses are being fed. A similar phenomenon was also recorded in the glaciated catchment of Petrel Creek where there was a levelling of the longitudinal profile of the creek and thaw-type depressions periodically filling with water (point Pt3). The aforementioned watercourse sections, in which changes in both water temperature and conductivity indicate changes in the nature of supply, also feature $\mathrm{pH}$ values changing along the longitudinal profile (Fig. 5). At the same time, taking into account the studied water parameters that were steadiest while the 2017 measurements were being taken, lower $\mathrm{pH}$ values were recorded in Ornithologists Creek (points O5 and O6, Fig. 4) as compared to previously reported $\mathrm{pH}$ values [20, 22, 25]. Animals living near Arctowski Station have a significant impact on the chemical properties of water [25]. It has been proven that seabirds living in polar areas transport biogenic compounds to land [24], which means that the water is in around Antarctic birds (e.g. south polar skua; Adelie, gentoo and chinstrap penguins) can be enriched with phosphorus and nitrogen [43]. In addition, the chemical status of the water in this section of the creek is shaped by the ornithogenic soils and penguin guano, which accounts for the slightly acidic condition of the water $[25,44]$. Droppings of the mammals (e.g. southern elephant seals and Weddell 
seals) living in the area where physicochemical measurements were taken are a source of $\mathrm{NO}_{3}{ }^{-}$in freshwater [25].

It is also worth noting that based on measurements and analyses of flowing water samples from Arctowski Oasis from January-March 2005 (measured and sampled twice weekly) by Nedzarek et al. [22], $\mathrm{Cl}^{-}$and $\mathrm{Na}^{+}$contents are higher in upper courses of the Czech Creek, Vanishing Creek and Petrified Creek as compared to the stream-mouth profiles. Based on analyses of soil samples, the authors concluded that $\mathrm{Ca}, \mathrm{Mg}, \mathrm{K}$ and $\mathrm{Na}$ contents increase with height above sea level. The $S E C_{25}$ and water temperature measurements in watercourses taken for the present study, together with field observations, indicate, however, that the spatial variation in concentrations of components associated with atmospheric transport may be greater than indicated by Nedzarek et al. [22]. These components accumulate in snow and ice, and migrate towards the bottom of the cryogenic layer [38, 45, 46]. It can therefore be assumed that local depressions are sedimentation traps for sediments and chemical elements. Fine-grained deposits may accumulate from sedimentation in situ (on the surface, in the snow cover), along with chemical components that accumulate partly as a result of their greater possibility of binding with small fractions. Moreover, sediments and chemicals may also be related to runoff as the snow cover on the surrounding slopes melts, or to runoff of meltwater from buried ice and/or permafrost. Fragments of buried ice exposed by surface erosion and linear erosion were observed in the analysed catchment areas, both glaciated and non-glaciated.

The basic physicochemical water parameters of paraglacial areas are highly variable over time, as a result of changing weather conditions. These conditions affect the flow of both matter and energy, and affect the pace of snow cover melting and glacier ablation. Previous studies have indicated increased $S E C_{25}$ and ion concentrations during the Antarctic summer in non-glaciated catchments. This is related to the declining share of snowmelt waters, raising the proportion of infiltration waters and waters originating from ground-ice melting $[22,25,38]$. In the glacial catchments during the summer season the amount of suspended matter in the watercourses increases, but the proportion of ions decreases, which reduces $S E C_{25}$ values. The repeated measurements in the summer of 2017 on the forefield of the Baranowski Glacier clearly indicate a relationship between $S E C_{25}$ values and glacier ablation intensity. At points F8, S1 and S2, an increase in $S E C_{25}$ was observed on January 24 (Fig. 4), which may be associated with a reduction in the proportion of ablation water in the creeks' flows. Decrease in glacier ablation was observed due to a drop in air temperature in the days preceding measurement (Fig. 2).

The conductivity results for samples from Spitsbergen vary depending on the region of the island. It was found that in samples collected from the Revelva catchment located in the vicinity of the Polish Polar Station, Hornsund, the values in July 2015 ranged from 35.0 to $80.1 \mu \mathrm{S} \cdot \mathrm{cm}^{-1}$, and in September $201556.0-135 \mu \mathrm{S} \cdot \mathrm{cm}^{-1}$ [47]. In turn, the value range of this physicochemical parameter in Tyvjobekken and Reindeer Creek, located in the NW part of the Wedel-Jarlsberg Land, in the Bellsund region of Spitsbergen was higher and ranged from 196 to $342 \mu \mathrm{S} \cdot \mathrm{cm}^{-1}$ [48]. Waters taken from these streams had a $\mathrm{pH}$ of 7.26 to 8.18. In addition, water samples taken from the Scott River in NW Wedel Jarlsberg Land (SW Svalbard) had a conductivity of $66.3-169 \mu \mathrm{S} \cdot \mathrm{cm}^{-1}$ and a $\mathrm{pH}$ of 7.41 to 8.79 [49]. For comparison, the results of conductivity samples of water originating from Mellville Island, Nunavut, Arctic Canada ranged from 5.00 to $1230 \mu \mathrm{S} \cdot \mathrm{cm}^{-1}$ in 2008 [50] and from 11.0 to $428 \mu \mathrm{S} \cdot \mathrm{cm}^{-1}$ in 2009 [51]. The upper limit of the value in 2008 is more than twice higher than the highest value of conductivity in water samples from King George Island. 
The authors of the article [49] showed a large impact of sea spray on water samples with the highest conductivity. The average $\mathrm{pH}$ was 7.80 in 2008 [50] and from 7.43 in 2009 [51]. These results are close to the average $\mathrm{pH}$ values of the water samples described in this article. Studies of water taken from the Chena River, Alaska have shown that their average conductivity is $192 \mu \mathrm{S} \cdot \mathrm{cm}^{-1}$ and $\mathrm{pH} 7.35$ [52].

\section{Conclusion}

The $\mathrm{pH}, S E C_{25}$ and water temperature measurements taken in a dense network of measurement points along watercourses and in lakes on the western coast of Admiralty Bay show that the variability in the determinants of water chemistry is greater than previously suggested. The parameters used in the research provide only limited information on the possible variation in concentrations of ions and spatial changes in the supply structure of water bodies. However, the study has the undoubted advantage of requiring only a relatively modest investment of time and money. It may therefore support the selection and verification of measurement points and interpretation of results of detailed chemical analyses.

The measurements conducted, which indicate a high variability of $T$ and $S E C_{25}$ along the watercourses, suggest some sections of the watercourses being more heavily fed by waters from the melting of buried ice of various origins (including permafrost). Analysis of the obtained data confirmed that the waters fed by glacial ablation have $S E C_{25}$ up to $100 \mu \mathrm{S} \cdot \mathrm{cm}^{-1}$. Waters in catchments without glacial supply that were longer under the influence of periglacial conditions had $\mathrm{SEC}_{25}$ within $100-250 \mu \mathrm{S} \cdot \mathrm{cm}^{-1}$. In addition, statistical analysis showed that samples taken from areas in the early deglaciated catchments (Petrified Forest Creek, Czech Creek, Ornithologists Creek) are characterized by a higher $\mathrm{pH} / \mathrm{SEC}_{25}$ ratio compared to water samples taken from the forefield of the glacier. These results testify to the significant impact of soil background (geochemical factor) and glacier retreat on the formation of surface water chemistry on the western coast of the Admiralty Bay. In addition, it was found that Siodlo II had the highest $\mathrm{pH}$ values (the most alkaline) and the lowest Ornithologists Creek (the most acidic). Considering the location of large numbers of birds and pinnipeds colonies around Ornithologists Creek, the obtained $\mathrm{pH}$ values may indicate significant impact on the chemical properties of water. The large variability of the measured parameters in the upper and middle courses of the streams suggests that the geochemical system of non-glaciated areas on the western shore of Admiralty Bay can only be fully understood with testing using a larger number of sampling points. At the same time, the measured parameters showed a high sensitivity to short-term fluctuations in weather conditions affecting changes in the structure of water supply, which indicates the need for frequent sampling. Such sensitivity of aquatic ecosystems to weather conditions can also affect the variability of other chemical substance concentrations.

The remarkable remoteness of the research area, and the number of samples being limited by the ability to store them in a frozen state at the station and deliver them to the laboratory in Poland, lead us to conclude that it would be a good solution to furnish the H. Arctowski station with equipment to conduct complex chemical analyses on site. The remote transport of samples poses a risk of changes in both the physicochemical parameters being measured and the concentrations of certain compounds, due to possible temperature changes and highly volatile compounds transitioning to the headspace phase. 
Extending the chemical laboratory at the Polish Polar Station would increase its scientific potential and thus enable the expansion of international cooperation.

\section{Acknowledgements}

The study was supported by grant No BS2016/5 "Transformation of river systems as a result of natural and anthropogenic factors" financed at Kazimierz Wielki University in Bydgoszcz. The data used in the paper were collected based at Henryk Arctowski Polish Antarctic Station. The authors would like to thank the staff of the Station for their assistance and companionship during fieldwork in 2017. Also, special thanks to Tomasz Budzik for field assistance and providing the meteorological data from the station located near the Arctowski Polish Antarctic Station. Moreover, the authors would also like to thank the SHIM-POL A.M. Borzymowski for their support during the Antarctic expedition.

\section{References}

[1] Mink S, Lopez-Martinez J, Maestro A, Garrote J, Ortega JA, Serrano E, et al. Insights into deglaciation of the largest ice-free area in the South Shetland Islands (Antarctica) from quantitative analysis of the drainage system. Geomorphology. 2014;225:4-24. DOI: 10.1016/j.geomorph.2014.03.028.

[2] Fountain AG, Levy JS, Gooseff MN, Van Horn D. The McMurdo Dry Valleys: A landscape on the threshold of change. Geomorphology. 2014;225:25-35. DOI: 10.1016/j.geomorph.2014.03.044.

[3] Oliva M, Ruiz-Fernández J. Coupling patterns between para-glacial and permafrost degradation responses in Antarctica. Earth Surf. Process. Landforms. 2015;40:1227-38. DOI: 10.1002/esp.3716.

[4] Oliva M, Ruiz-Fernández J. Geomorphological processes and frozen ground conditions in Elephant Point (Livingston Island, South Shetland Islands, Antarctica). Geomorphology. 2017;293:368-79. DOI: 10.1016/j.geomorph.2016.01.020.

[5] Vaughan DG, Marshall GJ, Connolley WM, Parkinson C, Mulvaney R, Hodgson DA, et al. Recent rapid regional climate warming on the Antarctic Peninsula. Climatic Change. 2003;60:243-74. DOI: 10.1023/A:1026021217991.

[6] Turner J, Colwell SR, Marshall GJ, Lachlan-Cope TA, Carleton AM, Jones PD, et al. Antarctic climate change during the last 50 years. Int J Climatol. 2005;25:279-94. DOI: 10.1002/joc.1130.

[7] Oliva M, Pereira P, Ruiz-Fernández J, Nieuwendam A. Recent advances in the study of active layer thermal regime and seasonal frost dynamics in cold climate environments. Catena. 2017;149:515-8. DOI: 10.1016/j.catena.2016.08.030.

[8] Mulvaney R, Abram NJ, Hindmarsh RCA, Arrowsmith C, Fleet L, Triest J, et al. Recent Antarctic Peninsula warming relative to holocene climate and ice-shelf history. Nature. 2012;489:141-5. DOI: 10.1038/nature11391.

[9] Bockheim J, Vieira G, Ramos M, López-Martínez J, Serrano E, Guglielmin M, et al. Climate warming and permafrost dynamics in the Antarctic Peninsula region. Glob Planet Change. 2013;100:215-23. DOI: 10.1016/j.gloplacha.2012.10.018.

[10] Kejna M, Araźny A, Sobota I. Climatic change on King George Island in the years 1948-2011. Pol Polar Res. 2013;34(2):213-35. DOI: 10.2478/popore-2013-0004.

[11] Birkenmajer K. Retreat of Ecology Glacier, Admiralty Bay, King George Island (South Shetland Islands, West Antarctica) 1956-2001. Bull Polish Acad Sci. 2002;50(1):15-29.

[12] Cook A, Fox A, Vaughan D, Ferrigno J. Retreating glacier fronts on the Antarctic Peninsula over the past half-century. Science. 2005;308(5721):541-4. DOI: 10.1126/science.1104235.

[13] Rückamp M, Braun M, Suckro S, Blindow N. Observed glacial changes on the King George Island ice cap, Antarctica, in the last decade. Glob Planet Change. 2011;79:99-109. DOI: 10.1016/j.gloplacha.2011.06.009.

[14] Pętlicki M, Sziło J, Macdonell S, Vivero S, Bialik RJ. Recent deceleration of the ice elevation change of ecology glacier (King George Island, Antarctica). Remote Sensing. 2017;9(6):520. DOI: 10.3390/rs9060520.

[15] Szilo J, Bialik RJ. Bedload transport in two creeks at the ice-free area of the Baranowski Glacier (King George Island, West Antarctica). Pol Polar Res. 2017;38(1):21-39. DOI: 10.1515/popore-2017-0003.

[16] Hawes I, Brazier P. Freshwater stream ecosystems of James Ross Island, Antarctica. Antarct Sci. 1991;3:265-71. DOI: 10.1017/S0954102091000329. 
[17] Wojtuń B, Fabiszewski J. Chemical properties of freshwater environment at the Admiralty Bay region (West Antarctica). Polish Polar Stud. XXVI Polar Symp. Lublin. 1999;393-9. http://geografia.umcs.lublin.pl/wyprawy/publikacje/sp11999/1999\%20art\%2049.pdf.

[18] Juchnowicz-Bierbasz M. Year-round changes of nutrients in fresh water bodies near Arctowski Station (South Shetland Islands, Antarctica). Pol Polar Res. 1999;20:243-58.

[19] Toro M, Camacho A, Rochera C, Rico E, Baňon M, Fernandez-Valiente E, et al. Limnological characteristics of the freshwater ecosystems of Byers Peninsula, Livingston Island, in Maritime Antarctic. Polar Biol. 2007;30(5):635-49. DOI: 10.1007/s00300-006-0223-5.

[20] Nędzarek A, Pociecha A. Limnological characterization of freshwater systems of the Thomas Point Oasis (Admiralty Bay, King George Island, West Antarctica). Polar Sci. 2010;4(3):457-67. DOI: 10.1016/j.polar.2010.05.008.

[21] Nędzarek A, Tórz A, Drost A. Selected elements in surface waters of Antarctica and their relations with the natural environment. Polar Res. 2014;33:21417. DOI: 10.3402/polar.v33.21417.

[22] Nędzarek A, Tórz A, Podlasińska J. Ionic composition of terrestrial surface waters in Maritime Antarctic and the processes involved in formation. Antarct Sci. 2015;27(2):150-61. DOI: 10.1017/S0954102014000522.

[23] Zwoliński Z, Kejna M, Rachlewicz G, Sobota I, Szpikowski J. Solute and sedimentary fluxes on King George Island. In: Beylich AA, Dixon J, Zwoliński Z editors. Source-to-Sink Fluxes in Undisturbed Cold Environments. Cambridge: Cambridge University Press; 2016:213-37. DOI: $10.1017 / \mathrm{CBO} 9781107705791.018$.

[24] Szopińska M, Namieśnik J, Polkowska Ż. How important is research on pollution levels in Antarctica? Historical approach, difficulties and current trends. Rev Environ Contam Toxicol. 2016;239:79-156. DOI: 10.1007/398_2015_5008.

[25] Szopińska M, Szumińska D, Bialik RJ, Chmiel S, Plenzler J, Polkowska Ż. Impact of a newly-formed periglacial environment and other factors on fresh water chemistry at the western shore of Admiralty Bay in the summer of 2016 (King George Island, Maritime Antarctica). Sci Total Environ. 2018;613-614:619-34. DOI: 10.1016/j.scitotenv.2017.09.060.

[26] IPCC. Summary for Policymakers. In: Stocker TF, Qin D, Plattner GK, Tignor M, Allen SK, Boschung J, et al., editors. Climate Change 2013, The Physical Science Basis. Contribution of Working Group I to the Fifth Assessment Report of the Intergovernmental Panel on Climate Change. Cambridge: Cambridge University Press; 2013:3-29. ISBN: 9781107057991. https://www.ipcc.ch/site/assets/uploads/2018/03/WG1AR5_SummaryVolume_FINAL.pdf.

[27] Kroto HW, Zielińska M, Rajfur M, Wacławek M. The climate change crisis? Chem Didact Ecol Metrol. 2016;21(1-2):11-27. DOI: 10.1515/cdem-2016-0001.

[28] Simões JC, Bremer UF, Aquino FE, Ferron FA. Morphology and variations of glacial drainage basins in the King George Island ice field, Antarctica. Ann Glaciol. 1999;29:220-4. DOI: 10.3189/172756499781821085.

[29] Pudełko R. Two new topographic maps for sites of scientific interest on King George Island, West Antarctica. Polish Polar Res. 2008;29(3):291-7.

[30] López-Martínez J, Serrano E, Schmid T, Mink S, Linés C. Periglacial processes and landforms in the South Shetland Islands (northern Antarctic Peninsula region). Geomorphology. 2012;155-156:62-79. DOI: 10.1016/j.geomorph.2011.12.018.

[31] Christensen JH, Hewitson B, Busuioc A, Chen A, Gao X, Held I, et al. Regional Climate Projections. In: Solomon S, Qin D, Manning M, Chen Z, Marquis M, Averyt KB, et al., editors. Climate Change 2007: The Physical Science Basis. Contribution of Working Group I to the Fourth Assessment Report of the Intergovernmental Panel on Climate Change. Cambridge: Cambridge University Press; 2007:849-940. ISBN: 9780521 88009-1. https://www.ipcc.ch/report/ar4/wg1/.

[32] Turner J, Barrand NE, Bracegirdle TJ, Convey P, Hodgson DA, Jarvis M, et al. Antarctic climate change and the environment - an update. Polar Record. 2014;50(3):237-59. DOI: 10.1017/S0032247413000296.

[33] Turner J, Lu H, White I, King JC, Phillips T, Hosking JS, et al. Absence of 21st century warming on Antarctic Peninsula consistent with natural variability. Nature. 2016;535:411-5. DOI: 10.1038/nature18645.

[34] Oliva M, Navarro F, Hrabáček F, Hernández A, Nývlt D, Pereira P, et al. Recent regional climate cooling on the Antarctic Peninsula and associated impacts on the cryosphere. Sci Total Environ. 2017;580:210-23. DOI: 10.1016/j.scitotenv.2016.12.030.

[35] Bockheim J, Vieira G, Ramos M, López-Martínez J, Serrano E, Guglielmin M, et al. Climate warming and permafrost dynamics in the Antarctic Peninsula region. Global Planetary Change. 2013;100:215-23. DOI: 10.1016/j.gloplacha.2012.10.018.

[36] Birkenmajer K. Admiralty Bay, King George Island (South Shetland Islands, West Antarctica): A geological monograph. Stud Geol Polon. 2003;120(14):5-73. http://www.polish.polar.pan.pl/ppr01/1980_1_029054.pdf. 
[37] Zwolicki A, Barcikowski M, Barcikowski A, Cymerski M, Stempniewicz L, Convey P. Seabird colony effects on soil properties and vegetation zonation patterns on King George Island, Maritime Antarctic. Polar Biol. 2015;38(10):1645-55. DOI: 10.1007/s00300-015-1730-z.

[38] Zwoliński Z. Mobilność materii mineralnej na obszarach paraglacjalnych, Wyspa Króla Jerzego, Antarktyka Zachodnia (The mobility of mineral matter in paraglacial areas, King George Island, Western Antarctica). Poznań: Wyd Naukowe UAM; 2007;74. ISBN: 9788323217244.

[39] Szymczak E. Particle Size Characteristics of Fluvial Suspended Sediment in Proglacial Streams, King George Island, South Shetland Island. IOP Conf. Ser.: Earth Environ. Sci. 2017;95:022015. DOI: $10.1088 / 1755-1315 / 95 / 2 / 022015$.

[40] Schaefer CEGR, Santana RM, Simas FNB, Francelino MR, Filho EIF, Albuquerque MA, et al. Geoenvironments from the vicinity of Arctowski Station, Admiralty Bay, King George Island, Antarctica: vulnerability and valuation assessment, U.S. Geological Survey and The National Academies. Short Research Paper 015. 2007:1047. DOI: 10.3133/of2007-1047.srp015.

[41] Myrcha A, Pietr SJ, Tatur A. The role of pygoscelid penguin rookeries in nutrient cycles at Admiralty Bay, King George Island. In: Siegfried WR, Condy PR, Laws RM. editors. Antarctic Nutrient Cycles and Food Webs. Springer Science \& Business Media. 2013:156-62. DOI: 10.1007/978-3-642-82275-9_2.

[42] Simas FNB, Schaefer CEGR, Michel RFM, Francelino MR, Bockheim JG. Soils of the South Orkney and South Shetland Islands, Antarctica. In: Bockheim JG, editor. The Soils of Antarctica. Springer Switzerland; 2015;227-73. DOI: 10.1007/978-3-319-05497-1_13.

[43] Nędzarek A. Sources, diversity and circulation of biogenic compounds in Admiralty Bay, King George Island, Antarctica. Antarct Sci. 2008;20(2):135-45. DOI: 10.1017/S0954102007000909.

[44] Zhu RB, Sun LG, Kong DM, Geng JJ, Wang N, Wang Q, et al. Matrix-bound phosphine in Antarctic biosphere. Chemosphere. 2006;64(1):1429-35. DOI: 10.1016/j.chemosphere.2005.12.031.

[45] Völkening J, Heumann KG. Determination of heavy metals at the pg/g level in Antarctic snow with DPASV and IDMS. Fresenius Z Anal Chem. 1988;331(2):174-81. DOI: 10.1007/BF01105162.

[46] Rose NL, Jones VJ, Noon PE, Hodgson DA, Flower RJ, Appleby PG. Long-range transport of pollutants to the Falkland Islands and Antarctica: Evidence from lake sediment fly ash particle records. Environ Sci Technol. 2012;46(18):9881-9. DOI: 10.1021/es3023013.

[47] Kosek K, Kozak K, Kozioł K, Jankowska K, Chmiel S, Polkowska Ż. The interaction between bacterial abundance and selected pollutants concentration levels in an arctic catchment (southwest Spitsbergen, Svalbard). Sci Total Environ. 2018;622-623:913-23. DOI: 10.1016/j.scitotenv.2017.11.342.

[48] Lehmann-Konera S, Franczak Ł, Kociuba W, Szumińska D, Chmiel S, Polkowska Ż. Comparison of hydrochemistry and organic compound transport in two non-glaciated high Arctic catchments with a permafrost regime (Bellsund Fjord, Spitsbergen). Sci Total Environ. 2018;613-614:1037-47. DOI: 10.1016/j.scitotenv.2017.09.064.

[49] Lehmann-Konera S, Kociuba W, Chmiel S, Franczak Ł, Polkowska Ż. Concentrations and loads of DOC, phenols and aldehydes in a proglacial arctic river in relation to hydro-meteorological conditions. A case study from the southern margin of the Bellsund Fjord - SW Spitsbergen. Catena. 2019;174:117-29. DOI: $10.1016 /$ j.catena.2018.10.049.

[50] Keatley BE, Douglas MSV, Smol JP. Evaluating the influence of environmental and spatial variables on diatom spiecies distributions from Melville Island (Canadian High Arctic). Botany. 2008;86:76-90. DOI: 10.1139/B07-118.

[51] Westover KS, Moser KA, Porinchu DF, MacDonald GM, Wang X. Physical and chemical limnology of a 61-lake transect across mainland Nunavut and southeastern Victoria Island, Central Canadian Arctic. Fundamental and Applied Limnology Archiv für Hydrobiologie. 2009;175/2:93-112. DOI: 10.1127/1863-9135/2009/0175-0093.

[52] Cai Y, Guo L, Douglas TA. Temporal variations in organic carbon species and fluxes from the Chena River, Alaska. Limnol Oceanogr. 2008;53(4):1408-19. DOI: 10.2307/40058262. 